Check for updates

Cite this: RSC Adv., 2017, 7, 50868

Received 16th August 2017

Accepted 17th October 2017

DOI: $10.1039 / \mathrm{c} 7 \mathrm{ra09063c}$

rsc.li/rsc-advances

\title{
Anti-inflammatory flavonol acylglycosides from the aerial part of Lindera akoensis Hayata $\dagger$
}

\author{
Hui-Chi Huang, (D) a Chung-Ping Yang, t $^{\mathrm{a}}$ Sheng-Yang Wang, ${ }^{\mathrm{bc}}$ Chi-I Chang, $\$^{\mathrm{d}}$ \\ Ping-Jyun Sung, $\dagger^{\text {ef }}$ Guan-Jhong Huang, (ID $\dagger^{\mathrm{a}}$ Shih-Chang Chien ${ }^{\star g}$ \\ and Yueh-Hsiung Kuo*ah
}

Five new flavonol acylglycosides, linderakosides A-E (1-5), together with 30 known compounds were isolated from the aerial part of Lindera akoensis Hayata. The structures were established using extensive spectroscopic analysis and comparison of NMR data with those of known compounds. The flavonol acylglycosides 1, 2, and 5 showed in vitro anti-inflammatory activity, which decreased LPS-stimulated nitrite production in RAW 264.7 cells. The structure activity relationships (SAR) of the flavonol acylglycoside compounds were also established to research for potential lead compounds as anti-inflammatory drugs.

\section{Introduction}

Lindera akoensis Hayata (Lauraceae) is an endemic large evergreen shrub that is widely distributed in Taiwan broad-leaved forests. This plant is a synonym of Benzoin akoense (Hayata) Kamik. ${ }^{1}$ L. akoensis has been used as a folk medicine for treatment of inflammation and trauma. ${ }^{2}$ Previous phytochemical studies revealed that the genus Lindera contains alkaloids, ${ }^{3}$ anthraquinone, ${ }^{4}$ aporphines, butanolides, ${ }^{5}$ essential oil, ${ }^{6}$ flavonoids, furanoids, chalconoids, ${ }^{5}$ phenolic compounds, ${ }^{7,8}$ and sesquiterpenoids.9,10 Earlier chemical and pharmacological studies on this endemic species of L. akoensis suggested that its butanolides account for its anti-inflammatory activities and antimycobacterial activities against Mycobacterium tuberculosis H37Rv. ${ }^{\text {5,11,12 }}$ Previous studies on the aerial part of $L$. akoensis resulted in isolation of 10 butanolides, five lignans, and five flavonols. ${ }^{5,11}$ In the present study, further detailed chemical investigation of the same 95\% ethanol extract of L. akoensis has

\footnotetext{
${ }^{a}$ Department of Chinese Pharmaceutical Sciences and Chinese Medicine Resources, China Medical University, Taichung 404, Taiwan

${ }^{b}$ Department of Forestry, National Chung-Hsing University, Taichung 402, Taiwan ${ }^{c}$ Agricultural Biotechnology Research Center, Academia Sinica, Taipei, 115, Taiwan ${ }^{d}$ Department of Biological Science and Technology, National Pingtung University of Science and Technology, Pingtung 912, Taiwan

${ }^{e}$ National Museum of Marine Biology and Aquarium, Pingtung 944, Taiwan

${ }^{f}$ Graduate Institute of Marine Biotechnology, National Dong Hwa University, Pingtung 944, Taiwan

${ }^{g}$ Experimental Forest Management Office, National Chung-Hsing University, Taichung 402, Taiwan. E-mail: scchien@nchu.edu.tw; Tel: +886-4-2284-0397 ext.600

${ }^{h}$ Department of Biotechnology, Asia University, Taichung 413, Taiwan. E-mail: kuoyh@mail.cmu.edu.tw; Tel: +886-4-2205-3366 ext.5709

$\uparrow$ Electronic supplementary information (ESI) available: ${ }^{1} \mathrm{H}$ and ${ }^{13} \mathrm{C}$ NMR spectra for new compounds 1-5. See DOI: 10.1039/c7ra09063c

\$ Equal contribution to this article.
}

resulted in isolation of five new flavonol acylglycosides (1-5) (Fig. 1), along with known compounds including three amides, eight apocarotenoids, 10 phenolic compounds, and nine porphyrinoids, which were isolated from this plant for the first time. Potential anti-inflammatory activity of isolates 1, 2, 4 and 5 was investigated via examining the inhibitory activity toward nitric oxide (NO) production induced by lipopolysaccharide in mouse macrophage RAW 264.7 cells tested in vitro (Table 1 ).

\section{Results and discussion}

The aerial part of L. akoensis was collected in Taiwan and extracted with $95 \%$ ethanol. The extract was partitioned into EtOAc and $\mathrm{H}_{2} \mathrm{O}$ layers. The EtOAc layer was purified using conventional chromatographic techniques yielding 35 compounds. Structures of the compounds were elucidated using spectroscopic techniques and these structures were compared with data from the literature.

Compound $\mathbf{1}$ was isolated as a pale yellow solid. The molecular formula $\mathrm{C}_{31} \mathrm{H}_{28} \mathrm{O}_{12}$ was determined on the basis of its HR-ESI-MS (calcd for $\mathrm{C}_{31} \mathrm{H}_{28} \mathrm{O}_{12} \mathrm{Na}, 615.1473$ ), which showed a pseudo-molecular ion peak at $m / z 615.1479$, corresponding to 18 degrees of unsaturation. The IR spectrum indicated the existence of a hydroxyl group $\left(3426 \mathrm{~cm}^{-1}\right)$, conjugated carbonyl group (1651 $\left.\mathrm{cm}^{-1}\right)$, and aromatic ring (1605 and $\left.1513 \mathrm{~cm}^{-1}\right)$. The UV absorption bands indicated $\lambda_{\max }$ at $267 \mathrm{~nm}(\log \varepsilon 4.56)$ and $313(\log \varepsilon 4.69) \mathrm{nm}$. The NMR spectra showed that 1 has a structure to similar to that of $4^{\prime}$-O-methylkaempferol-3-O- $\alpha$-L( $4^{\prime \prime}-E$-p-coumaroyl)rhamnoside, which has been isolated from this plant previously. ${ }^{5}$ This evidence suggests that $\mathbf{1}$ is a flavonoid glycoside derivative from its characteristic yellow color and spectral properties. The ${ }^{1} \mathrm{H}$, DEPT, and HSQC spectra of 1 indicated the presence of a 5,7-dihydroxy A ring system $\left[\delta_{\mathrm{H}} 6.20\right.$ 


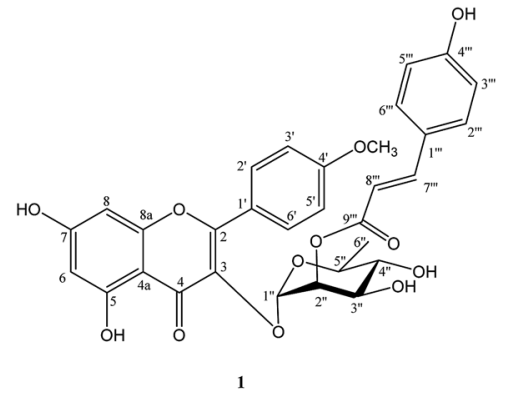<smiles></smiles><smiles></smiles><smiles>O=C(/C=C/c1ccc(O)cc1)OCCOc1oc2c(=O)c3c(O)cc(O)cc3oc2c1-c1ccc(O)c(O)c1</smiles>

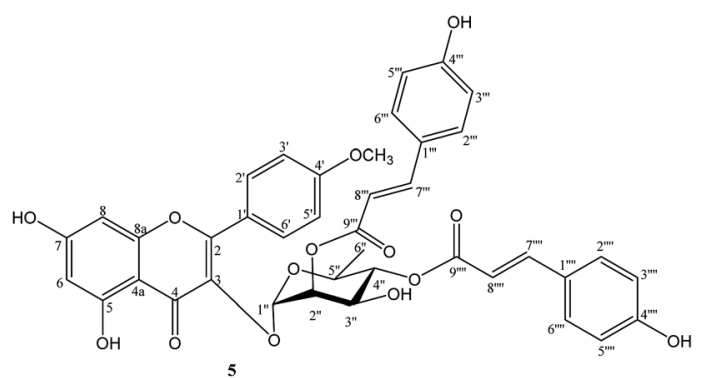

Fig. 1 Chemical structures of new compounds 1-5.

(d, $J=2.0 \mathrm{~Hz}, \mathrm{H}-6)$ and $6.38(\mathrm{~d}, J=2.0 \mathrm{~Hz}, \mathrm{H}-8)]$ and a 1,4disubstituted B ring $\left[\delta_{\mathrm{H}} 7.09\left(\mathrm{~d}, J=8.8 \mathrm{~Hz}, \mathrm{H}-3^{\prime}, 5^{\prime}\right)\right.$ and $7.88(\mathrm{~d}$, $\left.\left.J=8.8 \mathrm{~Hz}, \mathrm{H}-2^{\prime}, 6^{\prime}\right)\right]$ structure in flavonol, one sugar resonance $\left[\delta_{\mathrm{H}} 5.48\left(\mathrm{~d}, J=1.4 \mathrm{~Hz}, \mathrm{H}-1^{\prime \prime}\right) / \delta_{\mathrm{C}} 100.8\right]$, and a methoxy group $\left[\delta_{\mathrm{H}} 3.89 / \delta_{\mathrm{C}} 56.2\right]$. These data suggest that 1 contains a flavonol glycoside derivative. ${ }^{13}$ In the ${ }^{13} \mathrm{C}$ NMR spectrum of 1 , significant flavonol signals were observed at $\delta_{\mathrm{C}} 159.0$ (C-2), 136.0 (C-3), and
176.5 (C-4). The NOESY correlations between the methoxy singlet resonance with $\delta_{\mathrm{H}} 7.09\left(\mathrm{H}-3^{\prime}, 5^{\prime}\right)$ suggested location of a methoxy at C- $4^{\prime}$. HMBC correlations from $\delta_{\mathrm{H}} 7.88\left(2 \mathrm{H}, \mathrm{H}-2^{\prime}\right.$ and $\left.\mathrm{H}^{-} \mathrm{6}^{\prime}\right)$ to $\delta_{\mathrm{C}} 159.0(\mathrm{C}-2)$, as well as $\delta_{\mathrm{H}} 3.89\left(\mathrm{OCH}_{3}\right)$ to 163.7 $\left(\mathrm{C}-4^{\prime}\right)$, assumed that the aglycone of 1 was a kaempferide skeleton. ${ }^{14}$ For the glycone moiety, the carbon signal at $\delta_{\mathrm{C}} 100.8$ showed correlation with the anomeric proton at $\delta_{\mathrm{H}} 5.48$ in the

Table $1{ }^{1} \mathrm{H}$ NMR spectroscopic data of compounds $1-5$ (in $\left.\mathrm{CDCl}_{3}, 500 \mathrm{MHz}\right)^{a}$

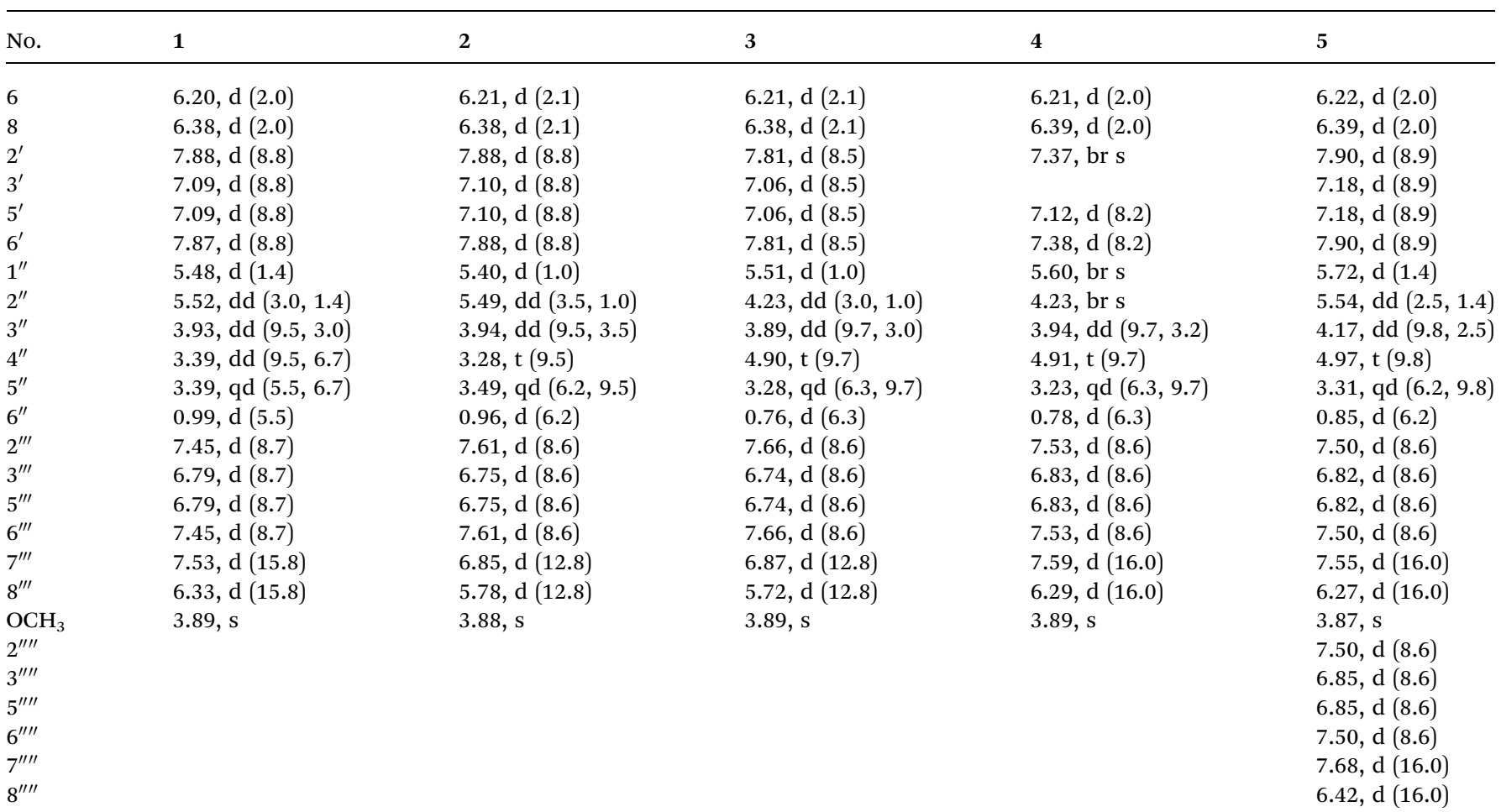

${ }^{a}$ The chemical shifts are expressed in $\delta$ ppm. The coupling constants $(J)$ are expressed in Hz. 
HSQC. The distinct methyl proton of Rha H-6 $\left(\delta_{\mathrm{H}} 0.99,3 \mathrm{H}, \mathrm{d}, J=\right.$ $5.5 \mathrm{~Hz})$ and small coupling constant $(J=1.4 \mathrm{~Hz})$ of the anomeric proton were assigned as a $\alpha$-L-rhamnopyranoside moiety using the characteristic ${ }^{1} \mathrm{H}$ NMR signals. The $\alpha$-L-rhamnopyranoside moiety was linked at C-3 of the flavone, from a cross-peak between $\mathrm{H}-1^{\prime \prime}\left(\delta_{\mathrm{H}} 5.48\right)$ of rhamnose and $\mathrm{C}-3\left(\delta_{\mathrm{C}} 136.0\right)$ of the aglycon. In addition, a 1,4-disubstituted aromatic ring $\left[\delta_{\mathrm{H}} 6.79\right.$ (d, $\left.J=8.7 \mathrm{~Hz}, \mathrm{H}-3^{\prime \prime \prime}, 5^{\prime \prime \prime}\right)$ and $\left.7.45\left(\mathrm{~d}, J=8.7 \mathrm{~Hz}, \mathrm{H}-2^{\prime \prime \prime}, 6^{\prime \prime \prime}\right)\right]$ as well as trans-olefinic signals $\left[\delta_{\mathrm{H}} 7.53\right.$ and 6.33 (each $1 \mathrm{H}, \mathrm{d}, J=15.8$ $\mathrm{Hz})$ ] were observed in the presence of an $(E)$-p-coumaroyl moiety. A detailed comparison of the ${ }^{13} \mathrm{C}-\mathrm{NMR}$ data between 1 and the afzelin literature data, ${ }^{15}$ the downfield shifts for C-2 ${ }^{\prime \prime}$ of Rha $(\Delta \delta+1.6 \mathrm{ppm})$ and upfield shifts for $\mathrm{C}-1^{\prime \prime}(\Delta \delta-2.7 \mathrm{ppm})$ and $\mathrm{C}-3^{\prime \prime}(\Delta \delta-1.9 \mathrm{ppm})$ of Rha, suggested that 1 was esterified at $\mathrm{C}-2^{\prime \prime}$. Furthermore, the HMBC correlation between the $\mathrm{H}-2^{\prime \prime}$ and $\mathrm{C}-9^{\prime \prime \prime}$ indicated that an $(E)$ - $p$-coumaroyl moiety was located at the $\mathrm{C}-2^{\prime \prime}$ position. Accordingly, the structure of $\mathbf{1}$ was elucidated as $4^{\prime}$-O-methyl- $2^{\prime \prime}-(E)-p$-coumaroylafzelin, and named linderakoside A.

Compound 2 was isolated as a pale yellow solid, with molecular formula obtained as $\mathrm{C}_{31} \mathrm{H}_{28} \mathrm{O}_{12}$ from HR-ESI-MS $(\mathrm{m} / \mathrm{z}$ 615.1477 [M $+\mathrm{Na}]^{+}$, calcd 615.1473) analyses with 18 degrees of unsaturation. IR and UV spectra were nearly the same as those of 1. 1D and 2D NMR spectra analyses established a kaempferide glycoside skeleton, which was also closely related to that of 1. Compound 2 was identified as the $Z$-isomer of $\mathbf{1}$, according to cis-olefinic protons at $\delta_{\mathrm{H}} 6.85$ and 5.78 (each $1 \mathrm{H}, \mathrm{d}, J=12.8 \mathrm{~Hz}$ ) in 1. Moreover, the $(Z)$ - $p$-coumaroyl moiety position was determined to be $\mathrm{C}-2^{\prime \prime}$ using the HMBC correlations between $\mathrm{H}-2^{\prime \prime}\left(\delta_{\mathrm{H}}\right.$ 5.47) and $\mathrm{C}-9^{\prime \prime \prime}\left(\delta_{\mathrm{C}}\right.$ 167.3). Based on the obtained data, compound 2 was determined as $4^{\prime}$-O-methyl-2" $2^{\prime \prime}(Z)-p$-coumaroylafzelin, and named linderakoside $\mathrm{B}$.

The molecular formula of compound $\mathbf{3}$ was given as $\mathrm{C}_{31} \mathrm{H}_{28} \mathrm{O}_{12}$ with 18 degrees of unsaturation from HR-ESI-MS at $m / z 615.1476[\mathrm{M}+\mathrm{Na}]^{+}$(calcd 615.1473), and compound 3 exhibited the same molecular weight as 2 . The NMR, UV, and IR data showed signal patterns similar to those of 2; however, the rhamnopyranose moiety substitution patterns differed. The ${ }^{1} \mathrm{H}$ NMR of rhamnose signals were easily assigned using the characteristic doublet signal of methyl. The ${ }^{1} \mathrm{H}-\mathrm{NMR}$ signal for Rha$6^{\prime \prime}\left(\delta_{\mathrm{H}} 0.76, \mathrm{~d}, J=6.3 \mathrm{~Hz}\right)$ shifted upfield $(\Delta \delta-0.20 \mathrm{ppm})$ compared with that of 2 , which was shielded by the flavone Cring, and the ${ }^{1} \mathrm{H}-\mathrm{NMR}$ signal of Rha- $4^{\prime \prime}\left(\delta_{\mathrm{H}} 4.90, \mathrm{t}, J=9.7 \mathrm{~Hz}\right)$ appeared relatively downfield $(\Delta \delta+1.51 \mathrm{ppm})$ using the esterified $p$-coumaroyl moiety. ${ }^{16}$ From ${ }^{13} \mathrm{C}$ NMR spectra comparison of 3 and 2 in the L-rhamnose moiety, the downfield shifts for Rha C-1" $(\Delta \delta+2.1 \mathrm{ppm})$ and Rha C-4" $(\Delta \delta+2.4 \mathrm{ppm})$ and upfield shifts of Rha C-2" $(-1.5)$ and $C-5^{\prime \prime}(-3.3)$ in 3, implied that the (Z)-p-coumaroyl moiety was located at Rha $\mathrm{C}-4^{\prime \prime}$ in 3 , instead of Rha C-2" as in 2. The HMBC correlation between $\delta_{\mathrm{H}}$ $4.90\left(\mathrm{H}-4^{\prime \prime}\right)$ and $\delta_{\mathrm{C}} 167.9\left(\mathrm{C}-9^{\prime \prime \prime}\right)$ of 3 indicated that the $(Z)-p$ coumaroyl moiety was located at the C-4 position. Thus, the structure of 3 was elucidated as $4^{\prime}$-O-methyl- $4^{\prime \prime}-(Z)-p$-coumaroylafzelin, and named linderakoside $\mathrm{C}$.

The molecular formula of compound $\mathbf{4}$ was obtained as $\mathrm{C}_{31} \mathrm{H}_{28} \mathrm{O}_{13}$ from HR-ESI-MS $\left(\mathrm{m} / \mathrm{z} 631.1423[\mathrm{M}+\mathrm{Na}]^{+}\right.$, calcd 631.1422) with 18 degrees of unsaturation, and thus contains one more oxygen atom than 1. The spectroscopic features of 4 were closely related to the spectroscopic features of $\mathbf{1}$, except for the presence of aromatic ABX-coupling signals $\left[\delta_{\mathrm{H}} 7.37(1 \mathrm{H}\right.$, br s), $7.12(1 \mathrm{H}, \mathrm{d}, J=8.2 \mathrm{~Hz})$, and $7.38(1 \mathrm{H}, \mathrm{d}, J=8.2 \mathrm{~Hz})]$ rather than a 1,4-disubstituted $\mathrm{B}$ ring structure in flavonol, and the rhamnopyranoside unit substitution patterns differed. The ${ }^{1} \mathrm{H}-\mathrm{NMR}$ data for 4 showed that an aromatic ABX-coupling system was ascribed to the presence of hydroxyl and methoxy substituents. The $4^{\prime}$-OMe was deduced according to a NOESY correlation between a methoxy proton $\left(\delta_{\mathrm{H}} 3.89\right)$ and $\mathrm{H}-5^{\prime}\left(\delta_{\mathrm{H}} 7.12\right)$ and $\mathrm{HMBC}$ correlation between $\delta_{\mathrm{H}} 3.89\left(\mathrm{OCH}_{3}\right)$ and $\delta_{\mathrm{C}} 152.0\left(\mathrm{C}-4^{\prime}\right)$, and thus the hydroxyl group was located at C-3' (Fig. 2). From the HMBC spectrum, the correlation between $\delta_{\mathrm{H}} 7.37\left(\mathrm{H}-2^{\prime}\right)$ and $\delta_{\mathrm{C}} 159.4(\mathrm{C}-$ 2), $152.0\left(\mathrm{C}-4^{\prime}\right), 148.0\left(\mathrm{C}-3^{\prime}\right)$, and $124.5\left(\mathrm{C}-1^{\prime}\right), \delta_{\mathrm{H}} 7.12\left(\mathrm{H}-5^{\prime}\right)$ and $\delta_{\mathrm{C}}$ $148.0\left(\mathrm{C}-3^{\prime}\right), 152.0\left(\mathrm{C}-4^{\prime}\right)$, and $124.5\left(\mathrm{C}-1^{\prime}\right)$, and $\delta_{\mathrm{H}} 7.39\left(\mathrm{H}-6^{\prime}\right)$ and $\delta_{\mathrm{C}} 159.4(\mathrm{C}-2), 112.7\left(\mathrm{C}-5^{\prime}\right), 131.4\left(\mathrm{C}-2^{\prime}\right)$, and $152.0\left(\mathrm{C}-4^{\prime}\right)$, assumed that the flavone moiety of $\mathbf{4}$ was tamarixetin. ${ }^{17}$ The characteristic doublet methyl signal $\left(\mathrm{CH}_{3}-6^{\prime \prime}\right)$ of rhamnose upfield $\left(\delta_{\mathrm{H}} 0.78, \mathrm{~d}, J\right.$ $=6.3 \mathrm{~Hz})$ and the triplet of $\mathrm{H}-4^{\prime \prime}$ downfield $\left(\delta_{\mathrm{H}} 4.91, \mathrm{t}, J=9.7 \mathrm{~Hz}\right)$ in 4 was the same as in 3, which suggested that the $(E)$-p-coumaroyl moiety was located at Rha C-4" in 4. HMBC spectrum inspection showed correlations between $\delta_{\mathrm{H}} 5.60$ (Rha-1") and $\delta_{\mathrm{C}}$ 135.7 (C-3) and between $\delta_{\mathrm{H}} 4.91$ (Rha-4") and $\delta_{\mathrm{C}} 168.9$ (C-9'"'), indicating Rha-C-1" linkage to C-3 of the flavone and of Rha-C-4" to $(E)$-p-coumaroyl-C-9'" , respectively. The above evidence was used to identify 4 as a $2^{\prime \prime}-(E)-p$-coumaroyltamarixetin, and the compound was named linderakoside $\mathrm{D}$.

With molecular formula calculated as $\mathrm{C}_{40} \mathrm{H}_{34} \mathrm{O}_{14}$ by HR-ESIMS $\left(m / z 761.1846[\mathrm{M}+\mathrm{Na}]^{+}\right.$calcd 761.1841), further combined with the observation of ${ }^{13} \mathrm{C}$ and DEPT spectra, compound 5 was suggested to have a similar kaempferide glycoside skeleton to 1 . Comparing 5 with 1, there were similarities in both the UV and IR data and the ${ }^{1} \mathrm{H}$ NMR spectra, but a difference appeared in the HR-ESI-MS analysis of one more $(E)$-p-coumaroyl moiety $\left(\mathrm{C}_{9} \mathrm{H}_{7} \mathrm{O}_{2}\right)$. In the ${ }^{1} \mathrm{H}$ NMR spectrum, ortho-coupled proton signals at $\delta_{\mathrm{H}} 7.50,6.85$ (each $\left.2 \mathrm{H}, \mathrm{d}, J=8.6 \mathrm{~Hz}, \mathrm{H}-2^{\prime \prime \prime \prime}, \mathrm{H}-6^{\prime \prime \prime \prime}\right)$ and trans-olefinic protons at $\delta_{\mathrm{H}} 7.68,6.42($ each $1 \mathrm{H}, \mathrm{d}, J=16.0 \mathrm{~Hz}$, $\left.\mathrm{H}-7^{\prime \prime \prime \prime}, \mathrm{H}-8^{\prime \prime \prime \prime}\right)$ indicated that 5 possessed an E-olefinic functionality. NMR data for $\mathbf{5}$ compared with those of $\mathbf{1}$ revealed the downfield shifts for Rha C-4" $(\Delta \delta+2.9 \mathrm{ppm})$ and upfield shifts of Rha C-3" $(-1.9)$ and C-5" $(-3.2)$ in 5 , suggesting an additional $p$-coumaroyl moiety at $\mathrm{C}-4^{\prime \prime}$. This conclusion was supported by the HMBC correlation between $\mathrm{H}-4^{\prime \prime}\left(\delta_{\mathrm{H}} 4.97\right)$ of the L-rhamnose and $\mathrm{C}-9^{\prime \prime \prime \prime}\left(\delta_{\mathrm{C}}\right.$ 168.4). Based on the above evidence, 5 was determined to be $4^{\prime}$-O-methyl-2" $4^{\prime \prime}$-di- $(E)$ - $p$-coumaroylafzelin, and named linderakoside $\mathrm{E}$.

The 30 known compounds including three amides, moupinamide (6), ${ }^{18} \mathrm{~N}$-p-coumaroyltyramine (7), ${ }^{19}$ and $\mathrm{N}$-trans-sinapoyltyramine (8), ${ }^{19}$ eight apocarotenoids, 4,5-dihydroblumenol A (9), ${ }^{20}$ epiloliolide (10), ${ }^{21} \quad(7 E)$-3 $\beta$-hydroxy-5 $\alpha, 6 \alpha$-epoxy-magastigmen-9one (11) ${ }^{22} 2 \alpha, 4 \beta$-dihydroxy-2,6,6-trimethylcyclohexanone $(12){ }^{23}$ $(3 S, 4 S, 5 S, 6 S, 9 R)-3,4$-dihydroxy-5,6-dihydro- $\beta$-ionone $(13),{ }^{24}$ boscialin (14), ${ }^{25}$ grasshopper ketone $(\mathbf{1 5}),{ }^{26}$ and loliolide (16), ${ }^{21} 10$ phenolic compounds, 2-hydroxymethyl-4-nitrophenol (17), ${ }^{27}{ }^{4-}$ hydroxy-3,5-dimethoxybenzaldehyde (18), ${ }^{28}$ isovanillin (19), ${ }^{28} p^{-}$ hydroxybenzaldehyde (20), ${ }^{29}$ vanillin (21), ${ }^{30} p$-hydroxybenzoic acid (22), ${ }^{31}$ 4-hydroxy-3-methoxynitrobenzene (23), ${ }^{32}$ trans-ferulatic 


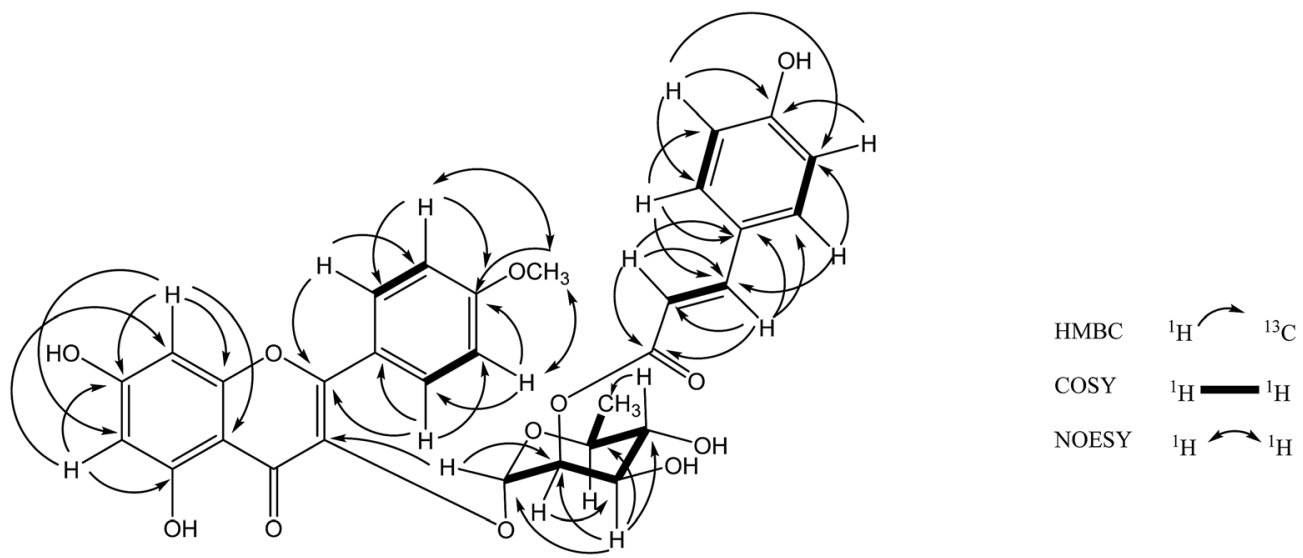

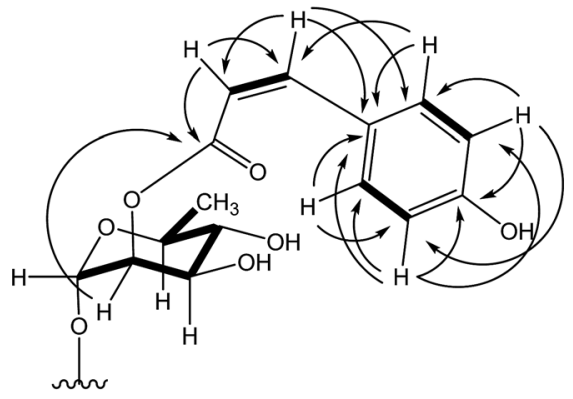

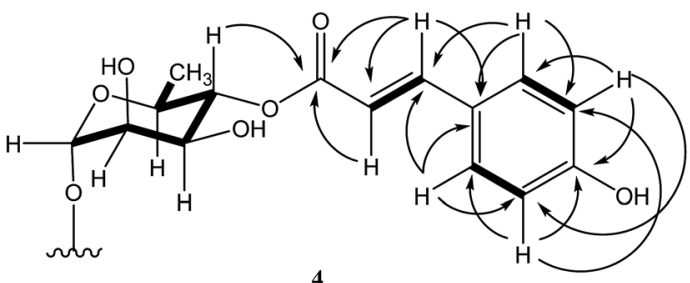

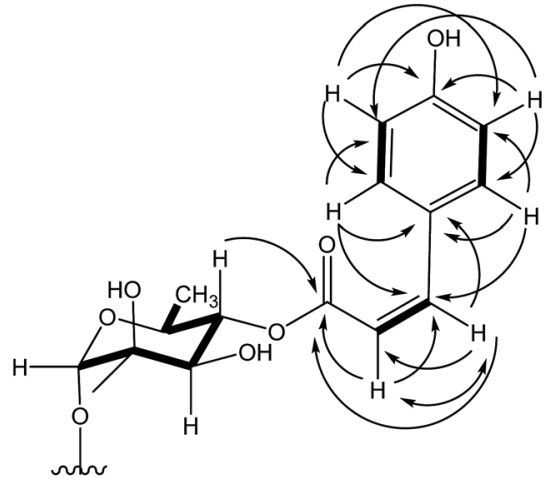

3

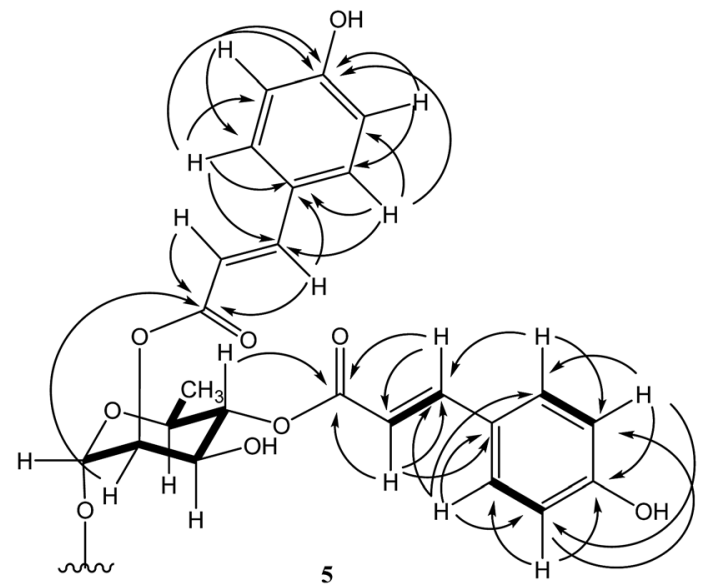

Fig. 2 Selected key HMBC, COSY, and NOESY correlations of compounds 1-5.

ester (24), ${ }^{33}$ 2-methyl-4-nitrophenol (25), ${ }^{34}$ and 3-hydroxy-4methoxybenzoic acid (26), ${ }^{35}$ and nine porphyrinoids, $\left(13^{2} R\right)-13^{2}$ hydroxypheophytin a $(27),{ }^{36}\left(13^{2} S\right)-13^{2}$-hydroxypheophytin a $(28),{ }^{36}$ pheophytin a (29), ${ }^{37}(10 S)$-pheophytin a (30), ${ }^{38}$ pheophytin b (31),,$^{39}$ aristophyll-C (32), ${ }^{36} 7^{\prime}$-oxoaristophyll-C $(33),{ }^{36}\left(13^{2} S\right)-13^{2}$-hydroxypheophytin b (34), ${ }^{36}$ and methyl rel- $\left(15^{1} R\right)-3^{1}, 3^{2}$-didehydro- $15^{1}$ hydroxy- $7^{1}$-oxo- $17^{3}$-O-phythylr-hodochlorin 15 -acetate $\delta$-lactone (35), ${ }^{\mathbf{4 0}}$ were identified by comparison of their physical and reported spectroscopic data (Table 2).
The potential anti-inflammatory activities of compounds $\mathbf{1}$, 2, 4, and 5 from L. akoensis were tested in vitro, by examining any decrease in LPS-stimulated nitrite production in RAW 264.7 cells (Table 3). Compounds 1, 2, and 5 exhibited significant inhibitory activities against nitric oxide production with $\mathrm{IC}_{50}$ values of $19.1,25.1$, and $9.4 \mu \mathrm{M}$, respectively. There was no significant change in cell viability among these active compounds (Table 3). These results are consistent with data from the literature on the kaempferide glycoside skeleton, in 
Table $2{ }^{13} \mathrm{C}$ NMR spectroscopic data of compounds $1-5$ (in $\mathrm{CDCl}_{3}$, $125 \mathrm{MHz}$ )

\begin{tabular}{|c|c|c|c|c|c|}
\hline No. & 1 & 2 & 3 & 4 & 5 \\
\hline 2 & 159.0 & 159.1 & 158.8 & 159.4 & 159.1 \\
\hline 3 & 136.0 & 136.1 & 136.0 & 135.7 & 135.2 \\
\hline 4 & 179.5 & 179.7 & 179.6 & 179.7 & 179.4 \\
\hline $4 a$ & 106.1 & 106.1 & 106.1 & 106.1 & 106.1 \\
\hline 5 & 158.7 & 158.7 & 158.8 & 158.8 & 158.8 \\
\hline 6 & 100.1 & 100.1 & 100.1 & 100.2 & 100.2 \\
\hline 7 & 166.1 & 166.1 & 166.3 & 166.3 & 166.2 \\
\hline 8 & 95.0 & 95.0 & 95.0 & 95.0 & 95.0 \\
\hline $8 a$ & 163.6 & 163.4 & 163.4 & 163.4 & 163.4 \\
\hline $1^{\prime}$ & 123.8 & 123.8 & 124.0 & 124.5 & 124.0 \\
\hline $2^{\prime}$ & 131.8 & 131.8 & 132.1 & 131.4 & 132.0 \\
\hline $3^{\prime}$ & 115.5 & 115.5 & 116.6 & 148.0 & 115.5 \\
\hline $4^{\prime}$ & 163.3 & 163.7 & 163.4 & 152.0 & 163.7 \\
\hline $5^{\prime}$ & 115.4 & 115.5 & 116.6 & 112.7 & 115.5 \\
\hline $6^{\prime}$ & 131.9 & 131.8 & 132.0 & 131.4 & 132.0 \\
\hline $1^{\prime \prime}$ & 100.8 & 100.8 & 102.9 & 102.5 & 99.5 \\
\hline $2^{\prime \prime}$ & 73.5 & 73.5 & 72.0 & 71.9 & 73.3 \\
\hline $3^{\prime \prime}$ & 70.8 & 70.7 & 70.2 & 70.3 & 68.6 \\
\hline $4^{\prime \prime}$ & 72.3 & 72.3 & 74.7 & 75.0 & 74.9 \\
\hline $5^{\prime \prime}$ & 73.7 & 73.2 & 69.9 & 69.9 & 69.9 \\
\hline $6^{\prime \prime}$ & 17.9 & 17.9 & 17.8 & 17.8 & 17.9 \\
\hline $1^{\prime \prime \prime}$ & 127.3 & 127.7 & 127.7 & 127.4 & 127.3 \\
\hline $2^{\prime \prime \prime}$ & 131.4 & 133.9 & 134.0 & 131.5 & 131.4 \\
\hline $3^{\prime \prime \prime}$ & 117.0 & 116.1 & 116.0 & 117.0 & 117.0 \\
\hline $4^{\prime \prime \prime}$ & 161.4 & 160.2 & 160.3 & 161.5 & 161.6 \\
\hline $5^{\prime \prime \prime}$ & 117.0 & 116.1 & 116.0 & 117.0 & 117.0 \\
\hline $6^{\prime \prime \prime}$ & 131.4 & 133.9 & 134.0 & 131.5 & 131.4 \\
\hline $7^{\prime \prime \prime}$ & 147.3 & 145.8 & 145.5 & 146.9 & 147.1 \\
\hline $8^{\prime \prime \prime}$ & 115.0 & 116.3 & 116.0 & 115.4 & 114.8 \\
\hline $9^{\prime \prime \prime}$ & 168.4 & 167.3 & 167.8 & 168.9 & 168.6 \\
\hline $\mathrm{OCH}_{3}$ & 56.2 & 56.2 & 56.3 & 56.7 & 56.3 \\
\hline $1^{\prime \prime \prime \prime}$ & & & & & 127.3 \\
\hline $2^{\prime \prime \prime \prime}$ & & & & & 131.4 \\
\hline $3^{\prime \prime \prime \prime}$ & & & & & 117.0 \\
\hline $4^{\prime \prime \prime \prime}$ & & & & & 161.6 \\
\hline $5^{\prime \prime \prime \prime}$ & & & & & 117.0 \\
\hline $6^{\prime \prime \prime \prime}$ & & & & & 131.4 \\
\hline $7^{\prime \prime \prime \prime}$ & & & & & 147.6 \\
\hline $8^{\prime \prime \prime \prime}$ & & & & & 115.1 \\
\hline $9^{\prime \prime \prime \prime}$ & & & & & 168.4 \\
\hline
\end{tabular}

which the $(E)$ or $(Z)-p$-coumaroyl moiety was located at Rha C-4" showing weak activity $\left(\mathrm{IC}_{50}>50 \mu \mathrm{M}\right) .{ }^{5}$ However, the $(E)$ or $(Z)-p$ coumaroyl moiety was located at Rha C-2" in compounds $\mathbf{1}$ and 2 rather than at Rha C-4" in compound 4, and showed the highest inhibitory effects $\left(\mathrm{IC}_{50}<25 \mu \mathrm{M}\right)$. The activities of Rha C-

Table 3 Cell viability and in vitro decrease of nitrite of LPS-stimulated production in RAW 264.7 cell activities of compounds $1,2,4$, and $5^{a}$

\begin{tabular}{lll}
\hline Compound & Cytotoxicity $\mathrm{IC}_{50}(\mu \mathrm{M})$ & $\begin{array}{l}\text { Inhibition of NO } \\
\text { production } \mathrm{IC}_{50}(\mu \mathrm{M})\end{array}$ \\
\hline $\mathbf{1}$ & $92.6 \pm 0.51$ & 19.1 \\
$\mathbf{2}$ & $92.2 \pm 0.47$ & 25.1 \\
$\mathbf{4}$ & $92.5 \pm 0.13$ & $>50$ \\
$\mathbf{5}$ & $90.9 \pm 0.40$ & 9.4 \\
Indomethacine & & $182.9 \pm 5.5$ \\
${ }^{a}$ Values are expressed as mean $\pm \mathrm{SD}$ of three replicates.
\end{tabular}

$2^{\prime \prime}$ with $(E)$-p-coumaroyl moiety (1) are better than Rha C-2" with (Z)-p-coumaroyl moiety (2). The disubstituted $(E)$-p-coumaroyl moieties of compound 5 were located at Rha C-4" and Rha C-2", and showed the strongest activity $\left(\mathrm{IC}_{50}<10 \mu \mathrm{M}\right)$. The monosubstituted (E)-p-coumaroyl group at Rha C-2" of compound 1 decreased activity. The observed structure-activity relationships (SAR) imply that the presence of the disubstituted $(E)-p$-coumaroyl groups at $\mathrm{C}-4$ and $\mathrm{C}-2$ of rhamnose moiety have an important role in enhancing the anti-inflammatory potential of kaempferide glycoside.

\section{Conclusions}

This study investigated chemically the aerial part of L. akoensis and isolated five new flavonol acylglycosides, linderakosides A-E (1-5) along with 30 known compounds, including three amides (6-8), eight apocarotenoids (9-16), 10 phenolic compounds (17-26), and night porphyrinoids (27-35). These compounds were isolated from this plant for the first time. Compounds 1, 2, and 5 displayed potential anti-inflammatory activity with $\mathrm{IC}_{50}$ values of 9.4-25.1 $\mu \mathrm{M}$, and exhibited no cytotoxic activity. These results provide a basis for evaluating the structure-activity relationships of flavonol acylglycosides, as well as for developing compound $\mathbf{5}$ as an anti-inflammatory drug.

\section{Experimental section}

\section{General experimental procedures}

Optical rotations were obtained in $\mathrm{MeOH}$ using a JASCO P-1020 digital polarimeter. IR and UV spectra were recorded on a Shimadzu IR Prestige-21 Fourier transform infrared and a Shimadzu Pharmaspec-1700 UV-Visible spectrophotometer, respectively. 1D and 2D NMR spectra were measured in $\mathrm{CDCl}_{3}$ and referenced to $\delta_{\mathrm{H}} 7.26$ and $\delta_{\mathrm{C}} 77.0$, and were recorded on a Bruker AVANCE III-500 MHz spectrometer. The HRESIMS data were recorded on a Finnigan LCQ ion-trap mass spectrometer. Column chromatography was performed using silica gel (Merck, 30-65 $\mu \mathrm{m}$ ), and TLC analysis was performed using aluminum pre-coated silica gel plates (Merck, Kieselgel $60 \mathrm{~F}_{254}$ ). HPLC was obtained with Shimadzu LC-6A apparatus equipped with an IOTA-2RI-detector. Phenomenex luna silica $(\Phi 250 \times 10$ column) were used for preparative purposes.

\section{Plant material}

The aerial part of $L$. akoensis was collected in Taichung, Taiwan, in July, 2008. This material was identified by Prof. Yen-Hsueh Tseng, Department of Forestry, National Chung Hsing University, Taichung, Taiwan. A voucher specimen (CMU2008-06-LA) was deposited in the School of Pharmacy, China Medical University.

\section{Extraction and isolation}

The dried aerial part of $L$. akoensis (5.9 $\mathrm{kg}$ ) was extracted with $95 \%$ ethanol for 7 days ( $20 \mathrm{~L}$, three times). The dried extract (337.8 g) was suspended in $\mathrm{H}_{2} \mathrm{O}$ and partitioned successively 
with ethyl acetate (EtOAc) and $n$-BuOH. The EtOAc layer was evaporated in vacuo to yield a residue (127.8 g) that was subjected to silica gel column chromatography (particle size $0.063-0.200$ $\mathrm{mm} ; \Phi 250 \times 15$ column) and eluted with a gradient of increasing polarity with solvent of $n$-hexane/EtOAc solvent (99: $1 \rightarrow 0: 100)$ to give 21 fractions. Fraction 3 (10.0 g) was separated using semipreparative HPLC $\left(\mathrm{CH}_{2} \mathrm{Cl}_{2} /\right.$ EtOAc, v/v $\left.4: 1\right)$ to afford pure, 25 (14.1 $\mathrm{mg}$ ), 26 (23.5 mg), 27 (16.2 mg), and 35 (4.5 mg). Fraction 11 (5.08 g) was fractioned after repeated chromatography over silica gel ( $n$ hexane/acetone, v/v $50: 1 \rightarrow 0: 100)$ to afford Fr. 11-1-11-10. Fr. 11-6 (109.5 mg) was chromatographed on semi-preparative HPLC $\left(\mathrm{CH}_{2} \mathrm{Cl}_{2} /\right.$ EtOAc, v/v $\left.7: 3\right)$ to afford $10(16.5 \mathrm{mg}), \mathbf{1 1}(2.1 \mathrm{mg}), \mathbf{1 2}(3.3$ $\mathrm{mg}$ ), 17 (6.2 mg), 18 (3.6 mg), and 21 (2.2 mg). Fr. 11-7 (98.7 mg) was further purified using semi-preparative $\mathrm{HPLC}\left(\mathrm{CH}_{2} \mathrm{Cl}_{2} / \mathrm{EtOAc}\right.$, $\mathrm{v} / \mathrm{v} 2: 1)$ to produce $24(3.4 \mathrm{mg}), 30(2.9 \mathrm{mg}), 31(4.1 \mathrm{mg}), 32$ (4.4 $\mathrm{mg}$ ), and 33 (2.3 mg). Fr. 11-8 (97.3 mg) was chromatographed on semi-preparative HPLC $\left(\mathrm{CH}_{2} \mathrm{Cl}_{2} /\right.$ EtOAc, v/v $\left.2: 1\right)$ to afford 19 (19.1 $\mathrm{mg}$ ), 20 (12.3 mg), 22 (9.6 mg), 28 (8.3 mg), and 29 (12.4 mg). Fraction 15 (6.82 g) was re-separated by chromatography and semipreparative HPLC (EtOAc/ $n$-hexane, v/v $1: 1)$ to afford pure 6 (6.6 $\mathrm{mg}), 9$ (9.8 mg), 23 (8.3 mg), and 34 (3.4 mg). Fraction 16 (7.15 g) was re-separated by chromatography and semi-preparative HPLC (EtOAc/n-hexane, v/v $2: 3$ ) to afford 1 (6.5 mg), 2 (4.6 mg), 3 (0.8 $\mathrm{mg}), 4$ (5.5 mg), 5 (6.5 mg), 7 (9.1 mg), and 8 (5.9 mg). Fraction 17 (1.25 g) was further passed over Sephadex LH-20 column and then purified by semi-preparative HPLC (EtOAc/ $n$-hexane, v/v $2: 3$ ) to yield 13 (7.7 mg), 14 (6.5 mg), 15 (3.7 mg), and 16 (3.5 mg).

4'-O-methyl-2" ${ }^{\prime \prime}$ - -p-coumaroylazfelin (1). Pale yellow solid; mp: $160-163{ }^{\circ} \mathrm{C} ;[\alpha]_{\mathrm{D}}^{24}-20.6(c 0.12, \mathrm{MeOH}) ; \mathrm{UV}(\mathrm{MeOH}) \lambda_{\max }$ (log $\varepsilon) 313.0$ (4.69), 277.0 (4.50), 267.0 (4.56), 247.0 (4.31), 211 (4.71) nm; IR $\nu_{\max } 3426,1651,1605,1513,1173 \mathrm{~cm}^{-1}$; HR-ESIMS $m / z: 615.1479[\mathrm{M}+\mathrm{Na}]^{+}$(calcd for $\mathrm{C}_{31} \mathrm{H}_{28} \mathrm{O}_{12} \mathrm{Na}, 615.1473$ ).

4'-O-methyl-2" $^{\prime \prime}$-Z-p-coumaroylazfelin (2). Pale yellow solid; $\mathrm{mp}: 169-170{ }^{\circ} \mathrm{C} ;[\alpha]_{\mathrm{D}}^{24}-29.3(c 0.98, \mathrm{MeOH}) ; \mathrm{UV}(\mathrm{MeOH}) \lambda_{\max }$ (log $\varepsilon) 313.0$ (4.60), 278.0 (4.48), 267.0 (4.57), 247.0 (4.34) nm, 211.0 (4.72); IR $\nu_{\max } 3426,1651,1605,1512,1173 \mathrm{~cm}^{-1}$; HR-ESIMS $m / z: 615.1477[\mathrm{M}+\mathrm{Na}]^{+}$(calcd for $\mathrm{C}_{31} \mathrm{H}_{28} \mathrm{O}_{12} \mathrm{Na}$, 615.1473).

4'-O-methyl-4" $-Z$-p-coumaroylazfelin (3). Pale yellow solid; mp: $162-164{ }^{\circ} \mathrm{C} ;[\alpha]_{\mathrm{D}}^{24}-24.5(c 0.23, \mathrm{MeOH}) ; \mathrm{UV}(\mathrm{MeOH}) \lambda_{\max }$ $(\log \varepsilon) 312.0$ (4.75), 247.0 (4.44), 211.0 (3.94) nm; IR $\nu_{\max }$ 3442, 2936, 1655, 1607, 1510, $1177 \mathrm{~cm}^{-1}$; HR-ESI-MS m/z: 615.1476 [M $+\mathrm{Na}]^{+}$(calcd for $\mathrm{C}_{31} \mathrm{H}_{28} \mathrm{O}_{12}, 615.1473$ ).

$\mathbf{4}^{\prime \prime}$-E-p-coumaroyltamarixetin (4). Pale yellow solid; mp: $200-$ $203{ }^{\circ} \mathrm{C} ;[\alpha]_{\mathrm{D}}^{24}-183.2(c 1.10, \mathrm{MeOH}) ; \mathrm{UV}(\mathrm{MeOH}) \lambda_{\max }(\log \varepsilon) 313.0$ (4.42), 276.0 (4.27), 267.0 (4.33), 246.0 (4.24), 208.0 (4.61) nm; IR $\nu_{\max } 3426,2932,1651,1604,1512,1173 \mathrm{~cm}^{-1}$; HR-ESI-MS $\mathrm{m} / z$ : $631.1423[\mathrm{M}+\mathrm{Na}]^{+}$(calcd for $\mathrm{C}_{31} \mathrm{H}_{28} \mathrm{O}_{13} \mathrm{Na}, 631.1422$ ).

$\mathbf{4}^{\prime}$-O-methyl-2" $\mathbf{4}^{\prime \prime}$-di- $\boldsymbol{E}$ - $\boldsymbol{p}$-coumaroylazfelin (5). Pale yellow solid; mp: $201-205{ }^{\circ} \mathrm{C}$; $[\alpha]_{\mathrm{D}}^{24}-88.8$ (c 1.18, MeOH); UV (MeOH) $\lambda_{\max }(\log \varepsilon) 314.0$ (4.97), 248.0 (4.44) nm, 212 (4.85) nm; IR $\nu_{\max }$ 3402, 2936, 1651, 1605, 1512, $1173 \mathrm{~cm}^{-1}$; HR-ESI-MS m/z: $761.1846[\mathrm{M}+\mathrm{Na}]^{+}$(calcd for $\mathrm{C}_{40} \mathrm{H}_{34} \mathrm{O}_{14} \mathrm{Na}, 761.1841$ ).

\section{Cell culture}

RAW264.7 (BCRC no. 60001) was purchased from the Bioresources Collection and Research Center (BCRC) of the Food
Industry Research and Development Institute (Hsinchu, Taiwan). Cells were maintained in plastic dishes containing Dulbecco's Modified Eagle Medium (DMEM, Sigma, St. Louis, MO, USA) containing $10 \%$ fetal bovine serum (FBS, Sigma, St. Louis, MO, USA, USA) with $5 \% \mathrm{CO}_{2}$ incubator at $37{ }^{\circ} \mathrm{C}$ and subcultured every 3 days at a dilution of $1: 5$ using $0.05 \%$ trypsin- $-0.02 \%$ EDTA in $\mathrm{Ca}^{2+}-\mathrm{Mg}^{2+}$-free phosphate-buffered saline (DPBS).

\section{Nitric oxide (NO) production assay ${ }^{41}$}

RAW 264.7 cells were incubated in a 96-well plate for $24 \mathrm{~h}$ and then pretreated with LPS (100 ng mL $\left.{ }^{-1}\right)$ with compounds (0, $3.125,6.25,12.5,25$ and $\left.50 \mu \mathrm{g} \mathrm{mL}{ }^{-1}\right)$. Then, the supernatant $(100$ $\mu \mathrm{L})$ was mixed with the same volume of Griess reagent $(1 \%$ sulfanilamide, $0.1 \%$ naphthyl ethylenediamine dihydrochloride and 5\% phosphoric acid) and incubated at room temperature for $10 \mathrm{~min}$; the absorbance was measured at $540 \mathrm{~nm}$ with a MicroReader (Molecular Devices Orleans Drive, Sunnyvale, CA, USA). Using sodium nitrite to generate a standard curve, the concentration of nitrite was measured from absorbance at $540 \mathrm{~nm}$.

\section{Cell viability assay ${ }^{11}$}

RAW 264.7 cells $\left(2 \times 10^{5}\right.$ cells per well $)$ were seeded in a 96-well plate containing DMEM medium with $10 \%$ FBS for $24 \mathrm{~h}$. Then cells were treated with various concentrations of compounds $\mathbf{1}, \mathbf{2}$, 4 , and 5 in the presence of $100 \mathrm{ng} \mathrm{mL}{ }^{-1}$ LPS (lipopolysaccharide) and incubated for $24 \mathrm{~h}$. After that, the cells were washed twice with DPBS and incubated with $100 \mu \mathrm{L}$ of $0.5 \mathrm{mg} \mathrm{mL}^{-1}$ MTT for $2 \mathrm{~h}$ at $37^{\circ} \mathrm{C}$ testing for cell viability. The medium was then discarded, and $100 \mu \mathrm{L}$ dimethyl sulfoxide (DMSO) was added. The absorbance with cell viability was determined using a microplate reader (Molecular Devices, Sunnyvale, CA, USA) at $570 \mathrm{~nm}$.

\section{Statistical analysis}

$\mathrm{IC}_{50}$ values were estimated using a non-linear regression algorithm (SigmaPlot 8.0; SPSS Inc., Chicago, IL, USA, 2002). Statistical evaluation was carried out by one-way analysis of variance (ANOVA followed by Scheffe's multiple range tests).

\section{Conflicts of interest}

There are no conflicts to declare.

\section{Acknowledgements}

This research was supported from China Medical University under the Aim for Top University Plan of the Ministry of Education, Taiwan (CHM 106-5-2 and CHM 106-4), Taiwan Ministry of Health and Welfare Clinical Trial and Research Center of Excellence (MOHW106-TDU-B-212-113004), and the Ministry of Science and Technology (MOST 103-2320-B-039-009MY3).

\section{Notes and references}

1 J. C. Liao, Flora of Taiwan, 2nd edn, 1996, vol. 2, pp. 456-458. 
2 Department of Health, Committee on Chinese Medicine and Pharmacy. The Catalogue of Medicinal Plant Resources in Taiwan, Taipei, Taiwan, 2003.

3 Y. C. Chang, C. Y. Chen, F. R. Chang and Y. C. Wu, J. Chin. Chem. Soc., 2001, 48, 811-815.

4 G. Wei, H. Chen, F. Nie, X. Ma and H. Jiang, Anti-Cancer Agents Med. Chem., 2015, 15, 1-4.

5 C. P. Yang, G. J. Huang, H. C. Huang, Y. C. Chen, C. I. Chang, S. Y. Wang, H. S. Chang, Y. H. Tseng, S. C. Chien and Y. H. Kuo, Int. J. Mol. Sci., 2013, 26, 9168-9181.

6 G. Wei, L. Kong, J. Zhang, C. Ma, X. Wu, X. Li and H. Jiang, Nat. Prod. Res., 2016, 6, 1-3.

7 J. P. Lei, G. Q. Wei, J. J. Yuan, K. Z. Tan, Q. Y. Chen, T. Zhang, C. Y. Ma and H. Z. Jiang, Nat. Prod. Res., 2017, 31, 896-901.

8 G. H. Ma, C. W. Lin, H. Y. Hung, S. Y. Wang, P. C. Shieh and T. S. Wu, Nat. Prod. Commun., 2015, 10, 2131-2133.

9 Q. Liu, Y. H. Jo, S. B. Kim, Q. Jin, B. Y. Hwang and M. K. Lee, Bioorg. Med. Chem. Lett., 2016, 26, 4950-4954.

10 J. S. Yu, J. Baek, H. B. Park, E. Moon, S. Y. Kim, S. U. Choi and K. H. Kim, Arch. Pharmacal Res., 2016, 39, 1628-1634.

11 C. P. Yang, G. J. Huang, H. C. Huang, Y. C. Chen, C. I. Chang, S. Y. Wang, I. S. Chen, Y. H. Tseng, S. C. Chien and Y. H. Kuo, Molecules, 2012, 17, 6585-6592.

12 S. Y. Chang, M. J. Cheng, C. F. Peng, H. S. Chang and I. S. Chen, Chem. Biodiversity, 2008, 5, 2690-2698.

13 T. Yahagi, A. Daikonya and S. Kitanaka, Chem. Pharm. Bull., 2012, 60, 129-136.

14 P. Curir, M. Dolci, V. Lanzotti and O. Taglialatela-Scafati, Phytochemistry, 2001, 56, 717-721.

15 L. A. Godínez, Rev. Soc. Quim. Mex., 1999, 43, 219-229.

16 S. G. Walmir, Y. Massayoshi and R. G. Otto, Phytochemistry, 1995, 39, 815-816.

17 W. J. Peng, Y. W. Li, C. S. Zhu, X. W. Han and B. Yu, Carbohydr. Res., 2005, 340, 1682-1688.

18 D. D. Moreira and G. G. Leitao, Phytochem. Anal., 2001, 12, 223-225.

19 Y. C. Chang, C. Y. Chen, F. R. Chang and Y. C. Wu, J. Chin. Chem. Soc., 2001, 48, 811-815.

20 Y. H. Kuo and Y. C. Li, J. Chin. Chem. Soc., 1997, 44, 321-325.

21 Y. H. Kuo, J. M. Lo and Y. F. Chen, J. Chin. Chem. Soc., 2002, 49, 427-431.

22 R. S. Burden and H. F. Taylor, Tetrahedron Lett., 1970, 11, 4071-4074.
23 N. Okada, K. Shirata, M. Niwano, H. Koshino and M. Uramoto, Phytochemistry, 1994, 37, 281-282.

24 C. Pérez, J. Trujillo, L. N. Almonacid, J. Trujillo, E. Navarro and S. J. Alonso, J. Nat. Prod., 1996, 59, 69-72.

25 J. Busch, Y. Grether, D. Ochs and U. Sequin, J. Nat. Prod., 1998, 61, 591-597.

26 B. Y. Hwang, B. N. Su, H. Chai, Q. Mi, L. B. Kardono, J. J. Afriastini, S. Riswan, B. D. Santarsiero, A. D. Mesecar, R. Wild, C. R. Fairchild, G. D. Vite, W. C. Ros, N. R. Farnsworth, G. A. Cordell, J. M. Pezzuto, S. M. Swanson and A. D. Kinghorn, J. Org. Chem., 2004, 69, 3350-3358.

27 Y. Zhou, G. Gao, H. Li and J. Qu, Tetrahedron Lett., 2008, 49, 3260-3263.

28 C. Y. Chen, F. R. Chang, C. M. Teng and Y. C. Wu, J. Chin. Chem. Soc., 1999, 46, 77-86.

29 K. Machida and M. Kikuchi, Phytochemistry, 1996, 41, 13331336.

30 S. Kobayashi, M. Kihara and Y. Yamahara, Chem. Pharm. Bull., 1978, 26, 3113-3116.

31 W. L. Lo, F. R. Chang, T. J. Hsieh and Y. C. Wu, J. Chin. Chem. Soc., 2002, 49, 421-426.

32 T. Ritter, K. Stanek, I. Larrosa and E. M. Carreira, Org. Lett., 2004, 6, 1513-1514.

33 K. Kawanishi and Y. Hashimoto, Phytochemistry, 1987, 26, 749-752.

34 W. B. Pan, L. M. Wei, L. L. Wei, C. C. Wu, F. R. Chang and Y. C. Wu, J. Chin. Chem. Soc., 2005, 52, 581-588.

35 H. Y. Ding, H. C. Lin, C. M. Teng and Y. C. Wu, J. Chin. Chem. Soc., 2000, 47, 381-388.

36 T. H. Lee, C. K. Lu, Y. H. Kuo, J. M. Lo and C. K. Lee, Helv. Chim. Acta, 2008, 91, 79-84.

37 M. Kobayashi, K. Ishida, S. Terabayashi and H. Mitsuhashi, Chem. Pharm. Bull., 1991, 39, 3348-3349.

38 S. Lötjönen and P. H. Hynninen, Synthesis, 1983, 9, 708-710.

39 Y. Nakatani, G. Ourisson and J. P. Beck, Chem. Pharm. Bull., 1981, 29, 2261-2269.

40 H. Y. Lin, H. L. Chiu, Y. H. Lan, C. Y. Tzeng, T. H. Lee, C. K. Lee, Y. Y. Shao, C. R. Chen, C. I. Chang and Y. H. Kuo, Chem. Biodiversity, 2011, 8, 1701-1708.

41 H. H. H. W. Schmidt and M. Kelm, in Methods in Nitric Oxide Research, John Wiley \& Sons Ltd., New York, 1996, ch. 33, pp. 491-497. 